\title{
The "Existential Turn" in Education as an Answer to Crises Facing an Individual
}

\begin{abstract}
The author characterizes a crisis as a complex and multidimensional phenomenon. She points out the ambivalence of crises, as they can lead to a final catastrophe or create good conditions for transgression. She argues that the absence of crises might be worrying and even pathological, as it may demonstrate the avoidance of challenges and no commitment to one's development. She refers to Theodor Adorno's idea of partial education and indicates some of its symptoms. Against that background, some fields of educational activity are discussed. In the author's opinion, they are essential for restoring the balance disturbed by a crisis as well as for using a crisis for the benefit of one's development.
\end{abstract}

Keywords: crisis, partial education, existential turn in education.

\section{„Zwrot egzystencjalny” w edukacji jako odpowiedź na kryzysy, wobec których staje człowiek}

\begin{abstract}
Abstrakt
Autorka charakteryzuje kryzys jako zjawisko złożone i wielowymiarowe. Wskazuje na ambiwalencję zjawisk kryzysowych, które z jednej strony mogą prowadzić do ostatecznej katastrofy, a z drugiej - tworzyć warunki do transgresji. Podkreśla, że brak zjawisk kryzysowych może być niepokojący, a nawet patologiczny, gdyż może być wyrazem unikania wyzwań i braku troski o rozwój. Nawiązując do Theodora Adorno, wskazuje na niektóre przejawy połowiczności edukacji. Na tym tle proponuje obszary, w których powinny być podjęte działania edukacyjne, aby człowiek umiał nie tylko przywracać zakłóconą kryzysem równowagę, lecz także wykorzystać kryzys na rzecz swego interesu rozwojowego.
\end{abstract}

Słowa kluczowe: kryzys, edukacja połowiczna, zwrot egzystencjalny w edukacji.

\footnotetext{
*University of Szczecin, Institute of Pedagogy.
} 


\section{Omnipresence of crises in the modern world}

Crisis is not a new category or phenomenon. At first, that notion was used in medicine and meant a sudden breakthrough in an illness. That meaning was introduced by Hippocrates in his work entitled Peri Archais Itriks. Aristotle, when using the term, associated it with two areas, a judgement and a decision. Since the middle of the $16^{\text {th }}$ century, i.e. since the beginnings of the market economy, we have dealt with economic crises, which are inseparably connected to that type of economy (cf.: Bochenek 2012: 148). In 1776, Thomas Paine, the Enlightenment writer and thinker, wrote a series of pamphlets entitled The American Crisis, where one of the first modern uses of "crisis" may be found (Szacki 1996: 52).

Nowadays, that term is used in various contexts and in many scientific disciplines; crisis itself seems omnipresent. It is interesting whether a single area of social life could be identified to which a crisis does not pertain. Today, we speak about a crisis of our civilization as well as crises in various dimensions of human life: environmental, religious, axiological, and moral crises, as well as a crisis of authority, education, health care, or the pension system. Readers would be able to add many other areas of social life (or institutions operating in those areas) which are recognized as experiencing a crisis. Sometimes, one may have the impression that crisis reaches to the very foundations of the life of modern societies, that it is comprehensive and global (see: Dobroczyński 1995: 7-8; Szewczak 2012: 223). In the foreword to Third Wave by Alvin Toffler published in Poland at the end of the 20th century, Wiktor Osiatyński wrote: "Crisis. Economic crisis. Social crisis. The crisis of an educational system. The crisis of a family. A crisis of everything" (1986: 7). It is worth noting that he wrote that at the time when means of mass communication were neither so widely used as today nor had so many possibilities. Nowadays, owing to communication technologies, each local crisis may be discussed in many, even quite remote places of the world and each individual crisis may become a subject of interest of entire virtual communities. That omnipresence of crisis was commented on quite mockingly by Jerzy Szacki:

Discussing the modern reality using a tone other than the lament has been recognized for quite a long time as both stupid and inappropriate in good company. (...). To gain the reputation of a wise, deep, or insightful person today, you have to complain a lot (...). For some time, intellectual innovativeness consists, most of all, in repeating clichés about the crisis experienced by our civilisation. (...) There are more illustrations and figures of speech than original ideas and statements, as those were constructed more or less two hundred years ago (Szacki 1996: 52).

Even if we are willing to share Szacki's opinion that crisis is an intellectual buzzword used more or less to explicate various phenomena, it is, nevertheless, difficult to ignore or underestimate the fact that diagnosticians of crisis include 
great thinkers such as Edmund Husserl, Mikołaj Bierdiajew, Hannah Arendt, Józef Tischner and many more (Huseserl 1993; Bierdiajew 1999; Arendt 2010; Tischner 1990).

What should not be omitted here either is the fact that crisis is one of the central categories of Erik Erikson's concept of psycho-social development of an individual, which is very popular today. In that concept, a crisis appears in each stage of life as a consequence of the conflict between a need dominating in the stage concerned and the denial of that need. Therefore, it is not a neurotic or traumatic crisis but a normative one. It is an intrinsic element of the process of development of an individual. It may even be said that it is a condition of development (Erikson 1982; Witkowski 2015). As a consequence, it becomes a common phenomenon.

It is hard not to notice that an individual is not immune to traumatic crises, regardless of the historic period in which they live. Who has not experienced at least one of the following critical situations: a rejection of love, a professional failure, the feeling of helplessness, a serious illness, or the loss of the meaning of life? Therefore, we speak and write about "human" crises which are experienced as a part of human subjectivity. In response to such crises, crisis intervention has been developed as a separate discipline of psychology of health, which asks questions about the manners of helping an individual in a crisis and about systemic, interdisciplinary, and multidimensional aid in a crisis (Płużek, Jacyniak 2006; Stochmiałek 2015; Pilecka 2004; Heszen-Niejodek 1995; Barbanel, Sternberg 2006).

\section{Crisis - semantic outlines}

Since it may affect so many diverse areas of our lives, crisis has a different form and demonstrates itself in a different manner in each of them. The term is used commonly and is even abused, so it is difficult to reach a consensus as to its meaning. When asking about what a nervous crisis, a ministerial crisis, a crisis of values or a crisis of civilisation have in common, Paul Ricoeur made the supposition that crisis is a pseudo-term which, when used in various areas, has only a "foggy" similarity (2006: 36).

It is worth considering whether searching for a semantic consensus is necessary at all. Multiple meanings of a term do not have to be a proof of its weakness. On the contrary, they may be treated as a demonstration of liveliness, dynamics, no fixation in a stiff form which is difficult to change. A wide range of meanings of crisis already appeared in ancient Greece (Stachewicz 2010: 8-10) and combined various elements at that time. Therefore, I am not going to analyse that term in detail here, as such analyses are available in a vast literature, also in publications which are not referred to in this paper. I will only draw the most general outlines of the meaning of that term which are essential for further analyses. 
Starting from the meaning of a crisis in the market economy, Wiktor Szewczak proposed a certain regularity which is a part of a crisis. It is a discontinuation of/inability to perform fundamental functions or roles by an institution or an individual. And, for instance, one may speak about a crisis of culture when it stops providing clear and transparent models of behaviour; a crisis of a state when it loses its ability to control specific important social processes and phenomena; and the crisis of education when the results of education include departure from values recognized by the community (Szewczak 2012: 224). Analogically, we may speak about a crisis of an individual when they lose control of the situation and themselves and are not able to function in a manner which is satisfactory to themselves and to others.

Those crises of an individual, or "human" crises, as one may say, may occur in various areas and pertain to various spheres of life. At least four fundamental areas may be identified: developmental crises, which affect each person but are normative rather than traumatic; situational crises. which are connected to sudden events which are hard to predict; environmental crises, caused by a catastrophe or resulting from serious natural phenomena; and existential crises, which are related to values and goals important for an individual. Zenomena Płużek and Aleksander Jacyniak (2006: 71-94) listed as many as ten forms of that latter type of crisis: a crisis of identity, an ethical crisis, a crisis of sacrum, a crisis of vocation, a crisis of trust in another individual, a crisis of community, an institutional crisis, and a crisis of attitudes.

The forms of crises listed above are discussed in more detail in other works (Płużek, Jacyniak: 2006: 71-94; James, Gilliland 2006: 28-29; Murawska 2009: 15-21). Here, I am going to repeat what Paul Ricour said that "a crisis is born at a crossroads where dedication fights with the tendency to inertia, escape, and desertion" (1990: 50). Therefore, it is related to a need to make a choice; it requires one to become open to new and unknown perspectives. It forces one to become active, involved, and imaginative and to think alternatively and creatively. It triggers uncertainty and fear, which are sometimes even paralysing, but it also creates an opportunity to live a life which is fuller, richer, and more valuable, and to overcome all which is fossilized, superficial, or devoid of true satisfaction and deep meaning.

It is worth emphasizing that not experiencing a crisis may be alarming or even pathological. It means that an individual is sliding on the surface of life and fails to notice its challenges, dilemmas, cracks, or tragedy. By failing to confront them, an individual has no chance to use developmental opportunities thoroughly. They lose their chance to face up to life in all its conditions and circumstances. For that reason, Marek Szulakiewicz found the right to difficulties (and, as I will add, the right to crises) equal to the right to humanity (2012: 14). 


\section{Care about "human" matters as an abandoned mission of education. Partial education}

In debates on education, political as well as scientific ones, individuals are treated more and more frequently as human capital, and educational institutions - as service companies ruled by business logic. Tomasz Szkudlarek even speaks about the educational discourse having been moved from pedagogy to economy (2001: 166). It is also where the competences to conceptualize what education is/should be have been moved. Perhaps it is a consequence of pedagogists having been exhausted with the pointlessness of debates on the sense and goals of education. Afraid of being suspected of dogmatism, behaving as usurpers, and ideological domination, we give up more and more often in pedagogy and education on explicit support of specific values and we withdraw from explicit formulation of goals. We move to a safe zone of analytic measurements of performance, treating efficiency as an axiologically neutral and technical issue. We rarely ask: What efficiency? Efficiency for whom?

As a consequence, we deal with the domination of the material and objective sphere in education, one which is external to an individual. In addition, that particular focus on the objective sphere is informational and concentrated on collecting atomized data. That leads to the fact that education starts to "watch" reality and, as such, it refers to things which are closed and past, without a possibility - as described by Ernst Bloch (1982: 53) - to keep up with the process, with limited abilities to transform in the direction of information-knowledge-wisdom. The effects of such education are defined in a quantitative manner, using standardized and quantitative tests (Rutkowiak 2010: 230-231), with no consideration on whether an individual has got stuck in objectivity, the here and now, without noticing that thinking has been replaced with watching and consideration - with calculation.

Theodor Adorno called education which reduces thinking to calculation and neutralizing the world ethically, and is expressed in perceiving the world in the categories of goals, a partial education (1990). It is a consequence of an aspiration to rule the world and of caring only about the efficiency of activity, assessed according to the triad of quickly, cheaply, and a lot. But those factors should not be exhaustive for education. Education limited only to that form does not reach issues which Jan Szczepański calls truly human matters, i.e. wisdom, hope, loneliness, suffering, life and death, or values (1988). And it is those issues that are particularly important in an individual's everyday life and they become even more important when one comes up against crises. 


\section{Existential reductionism of pedagogy and education}

Therefore, it seems justified to say that education as well as pedagogy as a reflection on education are quite distant from truly human matters today. They focus on the objective reality which is measurable and where the effect may be assessed in the form of a score in a test or an exam. This leads to existential reductions which result in an individual becoming a hostage of the market, consumption, and the main tendencies of pop culture as well as a prisoner of "silent beliefs". They are lonely and helpless in the face of life crises, difficulties, understanding themselves in the world and the world in themselves, searching for the sense of their life, becoming rooted in the world of values and meanings, hopelessness and despair, but also success and satisfaction ${ }^{1}$.

Attention was already drawn to this fact by Edmund Husserl in the last century. In his lecture in Vienna in 1935, when diagnosing the crisis of European humanity and searching for its roots, he spoke about the "lost rationalism" of the current science which results in the loss of the importance of science for people. The philosopher found that science lacked space for "all questions that may come to mind, questions about being and questions about the norm, questions about the socalled existence" (Husserl 1993: 49-50). That lack of space is exposed particularly in the situation of a crisis and it is most acute at that time.

Among the difficulties and needs of our life - we hear - science has nothing to say to us. That excludes, in principle, all those questions which are urgent for people experiencing revolutions fraught with consequences in our ill-fated times, questions about the sense or the lack of sense of the whole of human life (Husserl 1987: 4).

If we assume that crises, both normative and existential ones, are intrinsic to human life, that they are a non-reducible property of the human universe, pedagogy and education should become "existentially significant" and "existentially sensitive" or else they will become "partial". Ostensible importance, existential futility, and orientation to fictional and short-term values or goals (e.g. promotions, diplomas, or certificates) should be alien to them (Orzelska: 2014). What is needed is education which would serve the purpose of enabling an individual not only to cope with crises by restoring the status quo from before a crisis, but also to become stronger after a crisis, with a feeling of personal strength, enriched spiritual life, trust in oneself, with the purpose of making growth and development, appreciation of life, and greater dedication to life consequences of a crisis. Education which would lead to an active and responsible "attitude to one's existence" (Frankl 2009: 110).

\footnotetext{
${ }^{1}$ Challenges for an individual and sources of difficulties or crisis may include not only negative events or situations. They may also include positive situations, such as exceptional success. They change the manner of an individual's functioning radically. They require involvement of physical, mental, and spiritual resources to become adapted to changes resulting from those events (cf.: Holmes, Holmes, Rahe 1967: 213-218; Sęk 2001: 13-22).
} 


\section{Fields of educational care about human matters}

Care about human matters requires a prior answer to the question of who a human is. In the $18^{\text {th }}$ century, Immanuel Kant recognized that question as one of the four to which a philosopher should search for an answer. I am not so arrogant or unreasonable as to attempt to answer that question here and now. However, I would like to repeat after Władysław Stróżewski that a human is an imperfect being. That statement should not be shocking. If humans were perfect beings, which means "complemented" with all values which may be attributed to them, as well as "complete", which means fulfilled, finished, and ready, education would not be necessary and would even be impossible. Education assumes that humans have a dynamic structure, i.e. they become and change, and that is understood as the implication of a possibility of changing for the better.

Humans are imperfect and unfinished beings, ones which still demand fulfilment. That does not mean, however, that they should, as a result, be shaped or formed according to even the most beautiful vision or model. They should not, as an individual may only be changed from the inside; they are the only one with the power to make changes to themselves. That, on the other hand, does not mean that education is unnecessary. On the contrary, it is absolutely necessary, but only as an activity which is an aid in becoming, i.e. with the care about the most important human matter, that is to say about one's own humanity.

Therefore, to what could education pertain to make it care about human matters? My proposals are syncretic. They refer to various anthropological traditions. To a great extent, they are a consequence of my studies on education as a practice favouring the development of hope in an individual. They concern certain discoveries which should be made by each individual to provide themselves with a chance in coping with crises, regardless of the nature and origins of a crisis, to use the transgressive opportunities of a crisis. They are needed to prevent life from becoming a "temporary existence" (Frankl 2009: 114) with no orientation towards important goals and with no perspective for the future.

What seems a fundamental matter is the discovery of oneself as a being with potential, having an unknown oneself ahead while having already been formed somehow. All other discoveries will be connected to that original and fundamental one.

\section{Discovering no human in oneself}

The constant and repeated discovery of one's own "insufficient humanity" or no human in oneself is a condition of aspiring to a possible self, to the self one wishes to be and could be. The inability to discover that lack and the belief that one already is the person one could be was called by Jaspers the greatest hazard to which an 
individual is exposed. That hazard was defined more precisely by Abraham Joshua Heschel, scientist and rabbi: "Satisfaction with oneself begets senselessness and despair. (...) it is opium for fools" (2014: 148).

And, a bit further:

All that is creative in an individual is a result of a grain of dissatisfaction which has no end. (...) To fix and revive dissatisfaction of our intentions and achievements, to maintain and revive an appetite which has never been satisfied - that is our goal. True fulfilment of an individual depends on their communion with that which exceeds them (Heschel 2014: 149).

That is important all the more because we are dealing with the population of the world by a mass of individuals, as understood by Ortega y Gasset, who are satisfied with themselves and see no need to change themselves; school and culture beguile them with promises of self-realization while "the formula of humanity (its condition) is no fulfilment, neither here, nor now, nor tomorrow" (Szulakiewicz 2012: 32). Therefore, it is important that an individual recognizes, in themselves, a creator and, at the same time, a material, that they observe that the shape of their life and themselves depends on them.

The discovery of no human in oneself has nothing to do with a dangerous and ineffective telling others how to live. It is about creating opportunities for an individual to discover that they are a creator and a material at the same time and, as a result, that they have an influence on the shape of themselves and their life, remembering about the instruction of Master Eckhart:

An individual should never recognize their work as so successful and so fulfilled as to make them so free and self-confident in their works that their mind becomes idle and falls asleep (Eckhart 1988: 60).

\section{Discovery of the internal world as a space for an individual to become}

It is worth referring here to three modes of being in the world proposed by Rollo May: Umwelt or the world around us, connected to biological needs and instincts, one which we share with animals; Mitwelt or the social world related to interpersonal relationships; and Eigenwelt or one's own world which is the foundation for referring to that which is external and for lending a meaning (1995: 162-164). Considering the last, Eigenwelt, it seems important to know that we become human not only by communing with the world of people and things, but also by forming our own internal world, which is as important as all that is external for an individual. It is worth learning it and acting in it (axiological reflection, reflection on the sense of life) (cf.: Dubas 2000: 117-118). It is there that, as Kazimierz Dąbrowski indicated, developmental and creative phenomena take place, 
as well as, which is no less important, pathological phenomena, such as depression or neuroses (1986: 40-41). Learning one's internal world may lead to the feeling of being lost, of strangeness, pointlessness, or emptiness.

The internal world, which is available to self-consciousness and subject to reflection, is a source for the external world. It is there that one may (freely) introduce changes by referring to ideas and values. Without discovering one's internal world as an important space for becoming, an individual will be a guard of their own shackles and will end up, as described by Erich Fromm, "in the hell of self-imprisonment", being unable to reflect, to deliberate critically on the world, culture, and their own humanity. By abandoning care about the internal world, an individual becomes a "by-product of their own life", helpless in the face of crises, with no possibility to use the developmental opportunities created by them.

\section{Discovery of oneself as an area of cognition}

Alongside the investigation of riddles of the world, it is worth solving, gradually but regularly, the riddle which we are for ourselves. In the ancient tradition, the cognition of oneself, i.e. gnothi seauton, was a part of caring about oneself. It is important also today, as probing into the subtle spheres of the objective reality or understanding another individual is related to the cognition of oneself and one's own subjective conditions.

As an individual is both a being lasting over time and a process going on over a period of time (Stróżewski 2002: 67); the truth about an individual is not something which may be grasped, possessed for ever, and closed in a fixed formula. That truth, like an individual, is also a process going on for a period of time. In that situation, we should rather speak about an indefinite process of "becoming true", as Cezary Wodziński describes it (2008: 24), which means work lasting for one's whole life.

\section{Discovery of oneself as a problem and a secret}

I would like to refer here to the differentiation proposed by Gabriel Marcel of a problem and a secret. The identification of problems results in an abstract attitude to life, a disruption of the primal bond which internally connects the subject with reality. We identify a problem to analyse it and, in the end, solve it. A secret is something which is "metaproblematic" and transcendental, where problems may not be identified. We come closer to a secret to discover it and participate in it (Marcel 2001: 145-146). That work of differentiating between them is never completed; there are no final solutions. As a result, it is even more important and necessary that an individual is described as a being whose most important element is contradiction (Cassirer 2017: 27; Skarga 2007: 37, 39). 


\section{Discovery of oneself as a value}

Education realized with care about human matters should be an opportunity to discover an individual as a value, a value in itself, one which needs no justification, which does not depend on how much good and bad we have done in our lives, but on the fact that we are able to differentiate between good and bad and make choices. It is not who an individual is that proves their value, but who they can be (Heschel 2014: 32). I think that it is a condition for an individual not to live on the surface of life, but for them to be willing to make a piece of art out of themselves and their life. And it does not mean any spectacular action, as was written by Jacek Filek in his work entitled Tajna wielkość twego życia (The Secret Greatness of Your Life):

Life is not "a discipline" or "a competition", although some people treat it like a contest. (...) The greatness of your life is demonstrated in everyday reality, most often with no public around. (...) The greatness of a man as a man rather than a singer, a minister, a mathematician etc. is in itself simply something which is non-public, non-classifiable, and non-consumable (as a so-called success). And it has to stay that way (2010: 24-25).

That greatness of a man as a man does not depend on achievements and records, but on the everyday effort of recognizing that which is good and making choices.

\section{Should we fear the "existential turn" in education?}

An accusation could be made that the approach to education as care about human matters proposed here is related to an excessive focus of the subject on themselves, forces them into narcissism, and leads only to concentration on their own internal life. Such an attitude, it may be believed, is a version of human egoism. However, the care about human matters we discuss has little in common with the risk of egoism. The Bible mentioned the love of oneself as a model of love of other people. Thereby, the intrinsic value of each individual was confirmed. When commenting on that evangelical recommendation, Z. Bauman stated that respecting and confirming one's own value enriches the world in which we live together and makes it a more intriguing and joyful place. It means bringing new promises into the world (2003: 190). Therefore, it is an action for oneself and for the world. In that meaning, recognition becomes no less than a moral imperative. The ancient epimeleia heautou also had such an ethical dimension.

Fear could also be expressed that the understanding of the care about human matters presented here means promoting escapist behaviours towards the matters of the world and an escape from responsibility for the world. Not only is directing oneself towards one's own humanity not egoism, but it does not lead to an escape 
from the external world either. However, it assumes "a certain methodical withdrawal, gaining a distance from absorbing activities, from distractions brought by the reality" (Mounier 1960: 218). When constructing the concept of the original personality, Kazimierz Obuchowski (2000) found gaining a mental distance from oneself and the surrounding world as a key element of such a personality. It means that an individual should not deceive themselves that their everyday hustle and bustle around various matters is a truly human life, that owing to that distance from everyday life they should recognize their own "activation" as a costume (which is sometimes very attractive and alluring) worn by emptiness. They should take actions which would form them as an individual and, at the same time, they should refrain from falling into the trap of activism and should not disregard or abandon consideration, contemplation, and reflection, which may enable them to restore the energy necessary to come out of crises stronger and ready for fulfilment of other developmental goals.

Gaining a distance from the world also makes it easier for one to recognise ideas of oneself and life, ways of thinking and feeling, which are more or less blatantly imposed on an individual and which are characteristic of the modern mass culture. Care about human matters is not related to a dilatory, fearful, or disrespectful "silence" or "hiding" of a person. It is related rather to rejecting all which is deemed an empty and idle game or ritual. Such a selection of involvement is necessary to save strength for things on which it is really worth spending effort.

Jan Szczepański argued that

Improvement of oneself may take place only in the internal world; the perfection of the work in the external world may only be a reflection of the achieved development level of the internal world (1988: 25).

However, fears do concern something else, i.e. making any pedagogical and educational approaches absolute and explicit, recognizing them as the only ones that are right (Witkowski 2004: 19). Such action may in itself lead to crises - crises of science and an individual.

\section{References}

Arendt H. (2010) Między czasem minionym a przyszłym, transl. by M. Godyń and W. Madej, Warszawa, Aletheia.

Barbanel L., Sternberg R. J. (2006) Psychological intervention in times of crisis, New York, Springer Publishing Company.

Bierdiajew M. (1999) Głoszę wolność, transl. by H. Paprocki, Warszawa, Fundacja Aletheia. 
Bochenek M. (2012) Rozważania historyczno-semantyczne na temat kryzysów ekonomicznych, "Acta Universitatis Nicolai Copernici", 2, Ekonomia: 147-159.

Cassirer E. (2017) Esej o człowieku. Wprowadzenie do filozofii kultury, Warszawa, Wydawnictwo Aletheia.

Dąbrowski K. (1986) Trud istnienia, Warszawa, Wiedza Powszechna.

Dobroczyński B. (1995) Wstęp in: F. Capra, D. Steindl-Rast, T. Matus, Należeć do wszechświata. Poszukiwania na pograniczu nauki i duchowości, transl. by P. Pieńkowski, Kraków, Wydawnictwo Znak: 5-11.

Dubas E. (2000) Świat wewnętrzny jako przestrzeń życia człowieka in: Przestrzeń życiowa i społeczna ludzi starszych, M. Dzięgielewska (ed.), Łódź 2000: 117-128.

Erikson E. H. (1982) The Life Cycle Completed, New York-London, W. W. Norton.

Filek J. (2010) Życie, etyka, inni. Scherza i eseje filozoficzno-etyczne, Kraków, Wydawnictwo Homini: 24-29.

Frankl V. (2009) Człowiek w poszukiwaniu sensu. Głos nadziei z otchłani Holokaustu, transl. by A. Wolnicka, Warszawa, Wydawnictwo Czarna Owca.

Heschel A. J. (2014) Kim jest człowiek?, transl. by K. Wojtkowska, Łódź, Wydawnictwo Uniwersytetu Łódzkiego.

Heszen-Niejodek I. (1995) Doświadczenie kryzysu - szansa rozwoju czy ryzyko zaburzeń, Katowice, Uniwersytet Śląski.

Holmes T. H., Rahe R. H. (1967) The Social Readjustment Scale, "Journal of Psychosomatic Research", 11: 213-218.

Husserl E. (1993), Kryzys europejskiego człowieczeństwa a filozofia, transl. by J. Sidorek, Warszawa, Fundacja Aletheia.

Husserl E. (1987) Kryzys nauk europejskich a fenomenologia transcendentalna: wprowadzenie do filozofii fenomenologicznej, transl. by S. Walczewska, Kraków, Wydawnictwo Naukowe Papieskiej Akademii Teologicznej.

James R. K., Gilliland B. E. (2006) Strategie interwencji kryzysowej. Pomoc psychologiczna poprzedzająca terapię, transl. by A. Bidziński, Warszawa, PARPA.

Marcel G. (2001) Być i mieć, transl. by P. Lubicz, Warszawa, Instytut Wydawniczy "Pax". 
May R. (1995) O istocie człowieka: szkice z psychologii egzystencjalnej, transl. by M. Moryń, Z. Wiese, Poznań, Dom Wydawniczy Rebis.

Mistrz Eckhart (1988) Kazania i traktaty, transl. by J. Prokopiuk, Warszawa, Instytut Wydawniczy "Pax".

Mounier E. (1960) Co to jest personalizm? oraz wybór innych prac, transl. by A. Krasiński, Kraków, Społeczny Instytut Wydawniczy Znak.

Murawska A. (2009) Przywracanie nadziei. Oblicza pomocy telefonicznej, Szczecin, Wydawnictwo Print Group, Daniel Chrzanowski.

Orzelska J. (2014) W stronę pedagogiki istotnej egzystencjalnie. Życie i jego trudności $z$ energiq duchowq jako wyzwania pedagogiczne rezyduów tożsamości, Kraków, Oficyna Wydawnicza "Impuls".

Osiatyński W. (1986) Przedmowa in: A. Toffler, Trzecia fala, transl. by E. Woydyłło, Warszawa, Państwowy Instytut Wydawniczy: 7-22.

Pilecka B. (2004) Kryzys psychologiczny: wybrane zagadnienia, Kraków, Wydawnictwo Uniwersytetu Jagiellońskiego.

Płużek Z., Jacyniak A. (2006) Świat ludzkich kryzysów, Kraków, Wydawnictwo WAM.

Ricoeur P. (1990) Kryzys - zjawisko swoiście nowoczesne?, transl. by M. Łukasiewicz in: O kryzysie. Rozmowy w Castel Gandolfo, K. Michalski (ed.), Vol. 2, Warszawa, Społeczny Instytut Wydawniczy Znak: 36-58.

Sęk H. (2001) Stres krytycznych wydarzeń życiowych in: Zdrowie - Stres - Zasoby, H. Sęk, T. Pasikowski (eds.), Poznań, Wydawnictwo Fundacji Humaniora: 13-22.

Skarga B. (2007) Człowiek to nie jest piękne zwierzę, Kraków, Społeczny Instytut Wydawniczy Znak.

Stachewicz K. (2010) Kryzys jako kategoria filozoficzna, “Teologia i Moralność", 7: 7-15.

Stochmiałek J. (2015) Kryzysy życiowe osób dorosłych. Refleksje andragogiczne i edukacyjne, Warszawa, Wydawnictwo UKSW.

Stróżewski W. (2002) O wielkości: szkice z filozofii człowieka, Kraków, Społeczny Instytut Wydawniczy Znak.

Szacki J. (1996) Więcej i mniej niż trzy wieki, “Znak”, 1: 52-56.

Szczepański J. (1988) Sprawy ludzkie, Warszawa, Czytelnik. 
Szewczak W. (2012) O pojęciu kryzysu polityki in: Od teorii do praktyki politycznej, M. Kołodziejczak, R. Rosicki (eds.), Poznań, Wydawnictwo Naukowe UAM: 223-240.

Szkudlarek T. (2001) Ekonomia i etyka: przemieszczenia dyskursu edukacyjnego, “Teraźniejszość - Człowiek - Edukacja”, special issue: 165-191.

Szulakiewicz M. (2012) O człowieku w czasach trudnych. Urywki filozoficzne, Toruń, Wydawnictwo Naukowe Uniwersytetu Mikołaja Kopernika.

Tischner J. (1990) Kryzys myślenia in: O kryzysie. Rozmowy w Castel Gandolfo, K. Michalski (ed.), Vol. II, Kraków, Społeczny Instytut Wydawniczy Znak.

Witkowski L. (2004) W poszukiwaniu nowoczesnej formacji intelektualnej w polskiej pedagogice in: Pedagogika we współczesnym dyskursie humanistycznym, T. Lewowicki (ed.), Warszawa-Kraków: 19.

Witkowski L. (2015) Versus. O dwoistości strukturalnej faz rozwoju w ekologicznym cyklu życia psychodynamicznego modelu Erika H. Eriksona, Kraków, Oficyna Wydawnicza "Impuls".

Wodziński C. (2008) Dobre wychowanie. Platońskie przypisy do Nietzschego i Heideggera, "Przegląd Pedagogiczny", 1: 13-27. 